\title{
Front Matter: Volume 7549
}

, "Front Matter: Volume 7549," Proc. SPIE 7549, Lasers in Dentistry XVI, 754901 (1 April 2010); doi: 10.1117/12.861259

SPIE. Event: SPIE BiOS, 2010, San Francisco, California, United States 


\title{
PROGRESS IN BIOMEDICAL OPTICS AND IMAGING
}

Vol. 11, No. 2

\section{Lasers in Dentistry XVI}

\author{
Peter Rechmann \\ Daniel Fried \\ Editors
}

24-25 January 2010

San Francisco, California, United States

Sponsored and Published by

SPIE 
The papers included in this volume were part of the technical conference cited on the cover and title page. Papers were selected and subject to review by the editors and conference program committee. Some conference presentations may not be available for publication. The papers published in these proceedings reflect the work and thoughts of the authors and are published herein as submitted. The publisher is not responsible for the validity of the information or for any outcomes resulting from reliance thereon.

Please use the following format to cite material from this book:

Author(s), "Title of Paper," in Lasers in Dentistry XVI, edited by Peter Rechmann, Daniel Fried, Proceedings of SPIE Vol. 7549 (SPIE, Bellingham, WA, 2010) Article CID Number.

ISSN 1605-7422

ISBN 9780819479457

Published by

SPIE

P.O. Box 10, Bellingham, Washington 98227-0010 USA

Telephone +1 3606763290 (Pacific Time) · Fax +1 3606471445

SPIE.org

Copyright (C) 2010, Society of Photo-Optical Instrumentation Engineers.

Copying of material in this book for internal or personal use, or for the internal or personal use of specific clients, beyond the fair use provisions granted by the U.S. Copyright Law is authorized by SPIE subject to payment of copying fees. The Transactional Reporting Service base fee for this volume is $\$ 18.00$ per article (or portion thereof), which should be paid directly to the Copyright Clearance Center (CCC), 222 Rosewood Drive, Danvers, MA 01923. Payment may also be made electronically through CCC Online at copyright.com. Other copying for republication, resale, advertising or promotion, or any form of systematic or multiple reproduction of any material in this book is prohibited except with permission in writing from the publisher. The CCC fee code is 1605$7422 / 10 / \$ 18.00$.

Printed in the United States of America.

Publication of record for individual papers is online in the SPIE Digital Library.

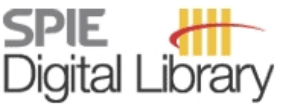

SPIEDigitalLibrary.org

Paper Numbering: Proceedings of SPIE follow an e-First publication model, with papers published first online and then in print and on CD-ROM. Papers are published as they are submitted and meet publication criteria. A unique, consistent, permanent citation identifier (CID) number is assigned to each article at the time of the first publication. Utilization of CIDs allows articles to be fully citable as soon they are published online, and connects the same identifier to all online, print, and electronic versions of the publication. SPIE uses a six-digit CID article numbering system in which:

- The first four digits correspond to the SPIE volume number.

- The last two digits indicate publication order within the volume using a Base 36 numbering system employing both numerals and letters. These two-number sets start with 00, 01, 02, 03, 04, $05,06,07,08,09,0 A, 0 B \ldots$. OZ, followed by 10-1Z, 20-2Z, etc.

The CID number appears on each page of the manuscript. The complete citation is used on the first page, and an abbreviated version on subsequent pages. Numbers in the index correspond to the last two digits of the six-digit CID number. 


\section{Contents}

$\checkmark$ Conference Committee

\section{LASERS IN DENTAL HARD TISSUE DIAGNOSTICS, IMAGING, AND ABLATION}

754902 Near-IR imaging of thermal changes in enamel during laser ablation [7549-02]

L. H. Maung, C. Lee, D. Fried, Univ. of California, San Francisco (United States)

754903 Analysis of dental abfractions by optical coherence tomography [7549-03]

E. Demjan, C. Mărcăuțeanu, D. Bratu, C. Sinescu, M. Negruțiu, Univ. de Medicina si

Farmacie Victor Babeş Timişoara (Romania); C. Ionita, State University of New York at Buffalo (United States); F. Topală, Univ. de Medicina si Farmacie Victor Babeş Timişoara (Romania); M. Hughes, A. Bradu, G. Dobre, A. Gh. Podoleanu, Univ. of Kent (United Kingdom)

754905 Imaging simulated secondary caries lesions with cross polarization OCT [7549-05] J. Stahl, H. Kang, D. Fried, Univ. of California, San Francisco (United States)

754906 Selective near-UV ablation of subgingival dental calculus: measurement of removal rates [7549-06]

J. E. Schoenly, W. Seka, Lab. for Laser Energetics, Univ. of Rochester (United States) and The Institute of Optics, Univ. of Rochester (United States); P. Rechmann, School of Dentistry, Univ. of California, San Francisco (United States)

754907 High-speed scanning ablation of dental hard tissues with a $\lambda=9.3-\mu \mathrm{m} \mathrm{CO} \mathrm{CO}_{2}$ laser: heat accumulation and peripheral thermal damage [7549-07]

D. Nguyen, M. Staninec, C. Lee, D. Fried, Univ. of California, San Francisco (United States)

754908 Laser brackets debonding: Tm:YAP and Clarity SL self-ligating appliance system [7549-08] T. Dostálová, Charles Univ. (Czech Republic); H. Jelínková, J. Šulc, P. Koranda, M. Němec, M. Jelínek, M. Fibrich, Czech Technical Univ. in Prague (Czech Republic); P. Michalik, Charles Univ. (Czech Republic); M. Miyagi, Sendai National College of Technology (Japan)

754909 Er:YAG laser debonding of porcelain veneers [7549-09]

N. BuU, C. Morford, F. Finzen, A. Sharma, P. Rechmann, School of Dentistry, Univ. of California, San Francisco (United States)

\section{POSTER POPS SESSION A}

7549 OA The impact of antimicrobial photodynamic therapy on Streptococcus mutans in an artificial biofilm model [7549-16]

M. Schneider, Univ. Dental Clinic Bonn (Germany); G. Kirfel, Univ. Bonn (Germany); F. Krause, M. Berthold, O. Brede, M. Frentzen, A. Braun, Univ. Dental Clinic Bonn (Germany) 
7549 OB Evaluation of the effect of photodynamic antimicrobial therapy in dentin caries: a pilot in vivo study [7549-17]

F. M. C. Borges, M. A. S. de-Melo, J. M. P. Lima, I. C. J. Zanin, L. K. A. Rodrigues, Federal Univ. of Ceará (Brazil); M. Nobre-dos-Santos, Piracicaba Dental School, State Univ. of Campinas (Brazil)

\section{LASERS IN CARIES PREVENTION, PERIODONTOLOGY, AND BIOSTIMULATION}

7549 OD Effects of 980 diode laser treatment combined with scaling and root planing on periodontal pockets in chronic periodontitis patients [7549-11]

A. Fallah, Aachen Institute for Laser Dentistry (Germany)

7549 OG Compositional and crystallographic changes on enamel when irradiated by Nd:YAG or $\mathrm{Er}, \mathrm{Cr}$ :YSGG lasers and its resistance to demineralization when associated with fluoride [7549-14]

D. M. Zezell, P. A. Ana, C. Benetti, V. P. Goulart, Instituto de Pesquisas Energéticas e

Nucleares, IPEN-CNEN/SP (Brazil); L. Bachmann, Univ. de São Paulo (Brazil);

C. P. M. Tabchoury, J. A. Cury, UNICAMP (Brazil)

\section{POSTER POPS SESSION B}

$7549 \mathrm{OH}$ Secondary caries detection with a novel fluorescence-based camera system in vitro [7549-21]

O. Brede, C. Wilde, F. Krause, M. Frentzen, A. Braun, Univ. Dental Clinic Bonn (Germany)

$7549 \mathrm{0J}$ In vitro study of the effect of a pulsed $10.6 \mu \mathrm{m} \mathrm{CO} 2$ laser and fluoride on the reduction of carious lesions progression in bovine root dentin [7549-23]

T. M. Parisotto, P. A. Sacramento, Piracicaba Dental School, Univ. of Campinas-UNICAMP (Brazill); M. C. Alves, Informatic Agricultural Ctr.-CIAGRI, Univ. of São Paulo (Brazil);

R. M. Puppin-Rontani, M. B. D. Gavião, M. Nobre-dos-Santos, Piracicaba Dental School, Univ. of Campinas-UNICAMP (Brazil)

7549 OK In vitro near-infrared imaging of occlusal dental caries using a germanium-enhanced CMOS camera [7549-24]

C. Lee, C. L. Darling, D. Fried, Univ. of California, San Francisco (United States)

$7549 \mathrm{OL} \quad$ Near-IR polarization imaging of sound and carious dental enamel [7549-25]

C. L. Darling, J. J. Jiao, C. Lee, H. Kang, D. Fried, Univ. of California, San Francisco (United States)

7549 OM Imaging early demineralization with PS-OCT [7549-26]

H. Kang, J. J. Jiao, C. Lee, C. L. Darling, D. Fried, Univ. of California, San Francisco (United States)

7549 ON Imaging natural occlusal caries lesions with optical coherence tomography [7549-27]

S. M. Douglas, D. Fried, C. L. Darling, Univ. of California, San Francisco (United States)

Author Index 


\title{
Conference Committee
}

\author{
Symposium Chairs \\ James G. Fujimoto, Massachusetts Institute of Technology \\ (United States) \\ R. Rox Anderson, Wellman Center for Photomedicine, Massachusetts \\ General Hospital (United States) and Harvard School of Medicine \\ (United States)
}

Program Track Chair

Reza S. Malek, Mayo Clinic (United States)

Conference Chairs

Peter Rechmann, University of California, San Francisco (United States)

Daniel Fried, University of California, San Francisco (United States)

Program Committee

Gregory B. Altshuler, Palomar Medical Technologies, Inc.

(United States)

Tatjána Dostálová, Charles University in Prague (Czech Republic)

John D. Featherstone, University of California, San Francisco

(United States)

David M. Harris, Bio-Medical Consultants, Inc. (United States)

Harvey A. Wigdor, Advocate Illinois Masonic Medical Center

(United States)

Session Chairs

1 Lasers in Dental Hard Tissue Diagnostics, Imaging, and Ablation

Peter Rechmann, University of California, San Francisco (United States)

2 Lasers in Caries Prevention, Periodontology, and Biostimulation

Daniel Fried, University of California, San Francisco (United States) 
Downloaded From: https://www.spiedigitallibrary.org/conference-proceedings-of-spie on 26 Apr 2023

Terms of Use: https://www.spiedigitallibrary.org/terms-of-use 